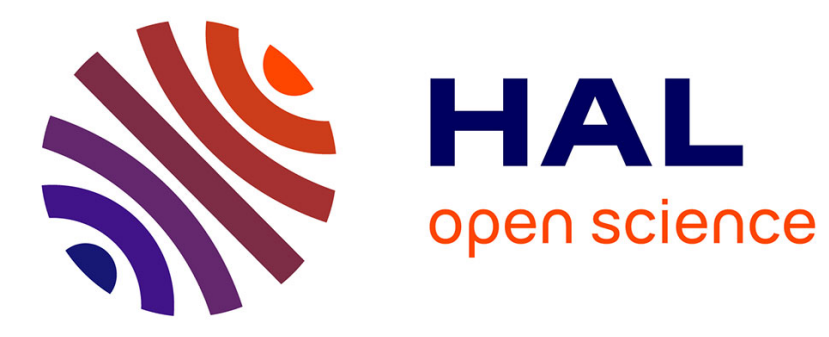

\title{
Human caspase-7 is positively controlled by SREBP-1 and SREBP-2
}

Laure Gibot, Julie Follet, Jean-Philippe Metges, Pierrick Auvray, Brigitte Simon, Laurent Corcos, Catherine Le Jossic-Corcos

\section{To cite this version:}

Laure Gibot, Julie Follet, Jean-Philippe Metges, Pierrick Auvray, Brigitte Simon, et al.. Human caspase-7 is positively controlled by SREBP-1 and SREBP-2: Caspase- 7 is a SREBP- $1 / 2$ target gene. Biochemical Journal, 2009, 420 (3), pp.473-483. 10.1042/BJ20082057 . hal-00479110

\section{HAL Id: hal-00479110 https://hal.science/hal-00479110}

Submitted on 30 Apr 2010

HAL is a multi-disciplinary open access archive for the deposit and dissemination of scientific research documents, whether they are published or not. The documents may come from teaching and research institutions in France or abroad, or from public or private research centers.
L'archive ouverte pluridisciplinaire HAL, est destinée au dépôt et à la diffusion de documents scientifiques de niveau recherche, publiés ou non, émanant des établissements d'enseignement et de recherche français ou étrangers, des laboratoires publics ou privés. 


\section{Human Caspase-7 is positively controlled by SREBP-1 and SREBP-2}

Laure Gibot ${ }^{*}$, Julie Follet ${ }^{*}$, Jean-Philippe Metges ${ }^{*} \dagger$, Pierrick Auvray $\dagger$, Brigitte Simon ${ }^{*}$, Laurent $\operatorname{Corcos}^{*}$, Catherine Le Jossic-Corcos ${ }^{* \S}$

*INSERM, UMR 613, ECLA team; IFR 148; Université de Brest, 22 Avenue Camille Desmoulins, 29238 Brest Cedex 3, France

${ }^{\ddagger}$ Department of Medical Oncology, Centre Hospitalier Universitaire Cavale Blanche et Morvan, Brest, France

$\dagger$ C.RIS Pharma, Parc Technopolitain Atalante Saint-Malo, 35400 Saint-Malo, France

\section{Footnotes :}

${ }^{\S}$ Corresponding author: Dr Catherine Le Jossic-Corcos

INSERM, UMR 613, ECLA team; IFR 148; Université de Brest, 22 Avenue Camille Desmoulins, 29238 Brest Cedex 3, France

Phone: 33298017902

Fax: 33298018322

e-mail : catherine.corcos@univ-brest.fr

Short title: Caspase-7 is a SREBP-1/2 target gene

Key words: Caspase-7, SREBP-1/2, lovastatin, apoptosis 


\begin{abstract}
Statins are lipid lowering drugs that may help limit cancer occurrence in humans. They drive blockage of the mevalonate pathway, trigger cancer cell apoptosis in vitro and reduce tumour incidence in animals. We show here that statins induced apoptosis in HGT-1 human gastric cancer cells, and this was prevented by intermediates of the cholesterol synthetic pathway. In addition, similarly to what we reported previously for caspase-2 (Logette, E., Le JossicCorcos, C., Masson, D., Solier, S., Sequeira-Legrand, A., Dugail, I., Lemaire-Ewing, S., Desoche, L., Solary, E. and Corcos, L. (2005) Mol Cell Biol 25, 9621-9631), caspase-7 may also be induced by statins and is under the positive control of Sterol Regulatory Element Binding Proteins-1 \& -2, major activators of cholesterol and fatty acids synthesis genes, in HGT-1 cells. Knocking down these proteins strongly reduced caspase-7 mRNA and protein expression, and chromatin immunoprecipitation analyses showed that the proximal promoter region of the $C A S P-7$ gene could bind either SREBP-1 or -2 . Strikingly, cells selected to grow in the continuous presence of statins showed increased expression of caspase- $7 \mathrm{mRNA}$ and protein, which was maintained in the absence of statins for several weeks, suggesting that high expression of this caspase might participate in adaptation to blunting of the mevalonate pathway in this model. Together, our results show that caspase- 7 , as a SREBP-1/2 target, can be induced under mevalonate restricting conditions, which might help overcome its shortage.
\end{abstract}




\section{INTRODUCTION}

Statins are HMG-CoA reductase competitive inhibitors that have long been used as efficient lipid lowering drugs in humans, but a large body of accumulated evidence suggests that they bear potential as anticancer agents in adjuvant therapy protocols [1-4]. Statins have been shown to trigger cancer cell apoptosis, and to decrease tumour incidence, tumour size or metastasis potential in animal models $[3,5,6]$. This was associated with a reduction in expression of the anti-apoptotic Bcl-2 and survivin proteins, up-regulation of pro-apoptotic members of the Bcl-2 family and caspase activation [7-9]. From a mechanistic point of view, statin-dependent apoptosis has been shown to be prevented by the addition of mevalonate, the product of HMG-CoA reductase activity [10].

Statin treatment leads to suppression of cholesterol and fatty acids synthesis, which triggers a compensatory feedback mechanism that aims at restoring lipid synthesis upon induction of many, if not all, genes encoding lipid biosynthetic enzymes and the Low Density Lipoprotein Receptor (LDLr) [11, 12]. This feedback mechanism is orchestrated by Sterol Regulatory Element Binding Proteins (SREBP), which become transcription activators when membrane cholesterol depletion is sensed, following transfer of their processed $\mathrm{N}$-terminal fragment into the nucleus $[13,14]$. This results in stimulation of lipid anabolism and uptake, and helps cells to restore their membrane lipid pool. Two genes encode SREBP proteins. The SREBP-1 gene encodes SREBP-1a and SREBP-1c, which differs from the former by a shorter first exon that codes for the N-terminal trans-activating function of the mature protein [15]. SREBP-2 is encoded by a different gene that codes for only one isoform [15]. The activities of SREBP-1 and SREBP-2 proteins overlap partially, but SREBP-1 is more involved in the control of fatty acids synthesis, whereas SREBP-2 is primarily involved in cholesterol synthesis in mice [16]. From results in transgenic mice over-expressing SREBP-1 or 2 proteins or deficient in Sterol Cleavage Activating Protein, it was shown that most SREBP-response genes code for lipid biosynthetic enzymes, but also for some other genes apparently unrelated [16].

Recently, we demonstrated that the human CASP-2 gene, encoding procaspase-2, was both a SREBP responsive gene and an important determinant of lipid synthesis in several cancer cell lines $[17,18]$. In addition, the CASP-2 gene was induced upon treatment by lovastatin, confirming that it was a bona fide SREBP response gene in human cells.

Here, we looked at the potential responsiveness of other caspases to statins in the human gastric cancer cell line HGT-1 [19]. Our results show that statins induced apoptosis in these cells, which was suppressed by intermediates of the mevalonate pathway and by both broad spectrum and specific caspase peptide inhibitors. We also identify $C A S P-7$ as a novel statinresponsive gene. Chromatin immunoprecipitation experiments showed that SREBP-1 \& 2 proteins could bind to the proximal promoter region of the $C A S P-7$ gene, which expression was suppressed upon silencing the SREBP-1\&-2 genes, indicating that the effect of SREBP proteins onto the $C A S P-7$ gene might be essentially direct. In addition, adaptation of HGT-1 cells to growth in presence of statins led to a stable rise in procaspase-7, suggesting that this caspase may help overcome the blockage of the mevalonate pathway brought about by statin treatment. 


\section{MATERIALS AND METHODS}

\section{Cell culture}

HGT-1 human gastric cancer cells were grown at $37^{\circ} \mathrm{C}$ under a humidified atmosphere of $5 \%$ $\mathrm{CO}_{2}$ in DMEM (Dulbecco's modified Eagle's medium) (Lonza, Saint Beauzire, France), containing $4.5 \mathrm{~g} / \mathrm{L}$ glucose and supplemented with $5 \%$ foetal bovine serum without antibiotics (Gibco-Invitrogen, Cergy Pontoise, France) [19].

The human HCT116 colon carcinoma cells (ATCC $n^{\circ}$ CCL-247) and the human $\mathrm{HepG}_{2}$ hepatoma cells (ATCC ${ }^{\circ} \mathrm{HB}-8065$ ) were maintained in DMEM/ Ham F12 medium (Lonza) without antibiotics and supplemented with $5 \%$ and $10 \%$ foetal bovine serum, respectively.

Selection of statin-resistant cell populations was performed with mass cultures grown in presence of serum-containing medium and 25 or $50 \mu \mathrm{M}$ lovastatin. Massive cell death occurred for several weeks under continuous selective pressure, after which the populations got stabilized and started to grow with no more signs of apoptosis. Then, lovastatin was removed from the culture medium for several cell doublings and the cells were challenged again with 25 or $50 \mu \mathrm{M}$ lovastatin. No more cell death occurred, and the population was considered as stably resistant to lovastatin. This procedure was applied successfully to HGT-1 (50 $\mu \mathrm{M}$ lovastatin) and HCT116 cells ( $25 \mu \mathrm{M}$ lovastatin).

\section{Chemicals}

All statins used in this study were purchased from Calbiochem (VWR, Fontenay sous Bois, France). They were dissolved in dimethylsulfoxide, except for fluvastatin and pravastatin, dissolved in water. The final concentration of dimethyl sulfoxide did not exceed $0.4 \%$, a concentration that did not induce any toxicity. Camptothecin and mevalonate (Sigma-Aldrich, Saint-Quentin Fallavier, France) were dissolved in dimethyl sulfoxide. Cholesterol (SigmaAldrich) was dissolved in ethanol. Caspase inhibitors were from RD systems (Lille, france) and dissolved in dimethyl sulfoxide. Farnesyl diphosphate (FPP) and geranylgeranyl diphosphate (GGPP) were purchased from Echelon Biosciences (Tebu-bio, Le Perray en Yvelines, France) and dissolved in water. Mevalonate concentration in cell culture medium or in pure foetal calf serum was determined according to Henneman et al.[20]

\section{Determination of apoptotic fragmentation and caspase activation}

The cells were treated with different doses of lovastatin or with camptothecin, known to induce apoptosis. Apoptosis was determined by Hoechst $33342(10 \mu \mathrm{g} / \mathrm{mL}$ in PBS $)$ staining of the cells for $15 \mathrm{~min}$ at $37^{\circ} \mathrm{C}$ and fluorescence microscopy analysis of 300 cells per condition. The activity of caspase- 3 + caspase- 7 was determined with the luminescent Caspase-Glo ${ }^{\mathrm{TM}}$ 3/7 Assay kit (Promega, France) according to the manufacturer's instructions. Briefly, the day before treatment, the cells were plated in 96 wells plates (20000 cells per well). After treatment, an equal volume of Caspase-Glo ${ }^{\mathrm{TM}} 3 / 7$ reagent was added to the sample in the assay well. Samples were incubated at $22^{\circ} \mathrm{C}$ for 1 hour and the enzyme activity was measured with a luminometer (Fluoroskan ascent FL, Thermo electron corporation).

DNA fragmentation was analysed by separation of $3 \mu \mathrm{g}$ of DNA in $1.8 \%$ agarose gels and staining with ethidium bromide. After treatment, cells were resuspended in lysis buffer (50 $\mathrm{mM}$ Tris- $\mathrm{HCl} \mathrm{pH} \mathrm{8,} 20 \mathrm{mM}$ EDTA, 1\% SDS) containing $200 \mu \mathrm{g} / \mathrm{ml}$ of proteinase K. After incubation at $56^{\circ} \mathrm{C}$ for $16 \mathrm{~h}$, DNA was purified by phenol/chloroform extraction and precipitated by addition of $0.3 \mathrm{M}$ sodium acetate and 2 volumes of ethanol. The precipitates were pelleted by centrifugation at $12000 \mathrm{~g}$ for $20 \mathrm{~min}$ at $4{ }^{\circ} \mathrm{C}$, air dried and resuspended in 10 $\mathrm{mM}$ Tris $\mathrm{HCl} \mathrm{pH} 8$ containing $1 \mathrm{mM}$ EDTA.

\section{RNA extraction and RT-PCR analysis}


Total RNA was isolated using Trizol (Invitrogen, Cergy-Pontoise, france). Samples of $2 \mu \mathrm{g}$ of total RNA were reverse-transcribed using random hexamers as primers and MMLV reverse transcriptase (New England Biolabs-Ozyme, Saint Quentin en Yvelines, France). Reverse transcription reactions ( $1 \mu \mathrm{l}$ out of $25 \mu \mathrm{l}$ reaction volume) were used as templates for all PCR experiments. The PCR primers used in this study were : acidic ribosomal phosphoprotein (P0), 5'-GCGACCTGGAAGTCCAACTA-3' (sense) and 5'TCTCCAGAGCTGGGTTGTTT-3' (antisense); HMG-CoA reductase (HMG-CoA red), 5'CGATGCATAGCCATCCTGTA-3' (sense) and 5'-TCAAGCCTGTCAATTCTTTGTC-3' (antisense); fatty acid synthase (FAS), 5'-GCTGGGTGGAGTCTCTGAAG-3' (sense) and 5'TGCAACACCTTCTGCAGTTC-3'(antisense); low density lipoprotein receptor (LDLr), 5'GCTTGTCTGTCACCTGCAAA-3' (sense) and 5'-AACTGCCGAGAGATGCACTT-3' (antisense); farnesyl pyrophosphate synthase (FPPS), 5'-AGGGCAATGTGGATCTTGTC-3' (sense) and 5'-GAAAGAACTCCCCCATCTCC-3' (antisense), Sterol Responsive Element Binding Protein-1 (SREBP-1), 5'-TGACTTCCCTGGCCTATTTG-3' (sense) and 5'TTCAATGGAGTGGGTGCAG-3' (antisense); Sterol Responsive Element Binding Protein-2 (SREBP-2), 5'-TGGACGTGGTGGTAGTGGTA-3' (sense) and 5'CTGAGGTGGGAGAAACCTTG-3' (antisense); caspase-3 (Casp3), 5' GACTCTAGACGGCATCCAGC-3' (sense) and 5'-TGACAGCCAGTGAGACTTGG-3' (antisense); caspase-6 (Casp6), 5'-GCCAGTCATTCCTTTGGATG-3' (sense) and 5'ATGAGCCGTTCACAGTTTCC-3' (antisense); caspase-7 (Casp7), 5' AGTGACAGGTATGGGCGTTC-3' (sense) and 5' CGGCATTTGTATGGTCCTCT-3' (antisense), caspase-9 (Casp9), 5'-GAGGGAGTCAGGCTCTTCCT-3' (sense) and 5'CTGGTCGAAGGTCCTCAAAC-3' (antisense).

\section{Chromatin immunoprecipitation analysis (ChIP)}

Chromatin immunoprecipitation (ChIP) assays were performed using the ChIP-IT kit (Active Motif Europe, Rixensart, Belgium) according to the manufacturer's instructions. Briefly, cells were fixed with formaldehyde for $10 \mathrm{~min}$ at room temperature to cross-link DNA with proteins, and then sheared chromatin was prepared enzymatically with a 10 min incubation time. After incubation with protein $G$ magnetic beads, the supernatants were immunoprecipitated with $2 \mu \mathrm{g}$ of $2 \mathrm{~A} 4$ anti-SREBP-1 (Santa Cruz/Tebu, Le Perrey en Yvelynes, France) or N19 anti-SREBP-2 (SantaCruz/Tebu) antibodies or with $2 \mu$ g negative control IgGs at $4^{\circ} \mathrm{C}$ overnight. The beads were then washed, the crosslinks reversed and the samples treated with proteinase K. For PCR (33 cycles), $5 \mu 1$ of eluted DNA or control input DNA were used. The primers used corresponded to the proximal promoter of the CASP-7 gene and were as follows: OL1s TTGGTCAGGGTGAACTGGAT (sense primer) and OL2as GATGCTGCTCCTGGATCTTT (antisense primer). PCR on material recovered for immunoprecipitation without antibody was also performed as a control. PCR products were visualized on $2.5 \%$ agarose gels containing ethidium bromide.

\section{Protein extraction and western blotting analysis}

Treated cells were harvested, washed in PBS and lysed in boiling buffer (1\% SDS, $1 \mathrm{mM}$ $\mathrm{Na}_{3} \mathrm{VO}_{4}, 10 \mathrm{mM}$ tris $\mathrm{pH}$ 7.4) containing protease inhibitor cocktail (Roche, Meylan France) for $10 \mathrm{~min}$ at $4^{\circ} \mathrm{C}$. Fifty micrograms of proteins were boiled in Laemmli buffer for $5 \mathrm{~min}$, separated by SDS-PAGE using $12 \%$ polyacrylamide gels and blotted onto polyvinyl difluoride membranes (Bio-Rad, Ivry-sur-Seine, France). Non specific binding sites were blocked for $1 \mathrm{~h}$ at room temperature by $5 \%(\mathrm{wt} / \mathrm{v})$ fat-free milk before an overnight incubation at $4^{\circ} \mathrm{C}$ with specific antibodies : rabbit anti-human procaspase-3, -6, -7 or -9 (Cell Signaling Tecnology-Ozyme, Saint Quentin en Yvelines, France), a rabbit anti-human PARP (Epitomics-Euromedex, Mundolsheim, France), mouse polyclonal anti-human SREBP-1a 
(2A4, Santacruz/Tebu), goat polyclonal anti-human SREBP-2 or with a rabbit anti-human HSC70 (Abcam, Paris, France) as a loading control. Primary antibodies were detected with a horseradish peroxidase-conjugated anti-mouse, anti-goat or anti-rabbit IgGs (Amersham, Orsay, France). Blots were revealed using an Enhanced Chemilumiscescence dectection kit (Amersham, Orsay, France) by autoradiography.

\section{Small interfering RNA (siRNA) transfections}

Sense and antisense SREBP-1 (sense strand RNA sequence, 5'CAACCAAGACAGUGACUUC-3'), SREBP-2 (sense strand RNA sequence, 5'CAACAGACGGUAAUGAUCAUU-3'), caspase-7 (sense strand RNA sequence, 5'CCGUCCCUCUUCAGUAAGA-3') and negative (ref: OR-0030-neg05) oligoribonucleotides were purchased from Eurogentec (Seraing, Belgium). HGT-1 cells were seeded into 6-well plates at the density of $1.10^{5}$ cells/well the day before transfection and then transfected by adding $5 \mu \mathrm{l}$ of Lipofectamine 2000 reagent to $5 \mu \mathrm{l}$ of $20 \mu \mathrm{M}$ siRNAs (final concentration 100 $\mathrm{nM})$ in serum-free medium. Four hours after transfection the medium was supplemented with serum and then maintained in culture for $72 \mathrm{~h}$ before analysis. 


\section{RESULTS and DISCUSSION}

\section{1) Statins trigger HGT-1 cells apoptosis}

The cytotoxic activity of statins has been largely documented in several types of cancer cells. However, little is known about gastric cancer cells. In order to analyse the effect of statins in such cells, we used the HGT-1 line, which has been isolated several years ago from an adenocarcinoma of the stomach [19]. Several statins were used at the concentrations of 25 and $50 \mu \mathrm{M}$. As observed with Hoescht 33342 staining, lovastatin, mevastatin, fluvastatin and simvastatin triggered $30-50 \%$ cells with fragmented nuclei, whereas pravastatin had only marginal activity (figure 1A). The fact that pravastatin was relatively inefficient has been already observed in several other cell models [9]. It was shown that apoptotic effects of pravastatin could be observed for very high concentrations, above $100 \mu \mathrm{M}$ that were not used here [21]. In addition, the rise in caspase (3/7) activity, a biochemical marker of ongoing apoptosis, strictly followed the relative levels of cell death induced by the various statins, as determined by activation of caspase (3/7) cleavagedependent luciferase (caspase $\mathrm{Glo}^{\mathrm{TM}}$ reagent) (figure $1 \mathrm{~B}$ ).

To get a more complete picture of apoptosis induction in HGT-1 cells, we focussed on the effects of lovastatin. Both dose- and time-dependency of apoptosis were observed upon lovastatin treatment: $15 \%$ apoptosis induction was detected with $5 \mu \mathrm{M}$ lovastatin for $48 \mathrm{~h}$, and $30 \%$ apoptosis were attained after $96 \mathrm{~h}$ with the same concentration of lovastatin, while more than $60 \%$ apoptosis occurred with $50 \mu \mathrm{M}$ lovastatin for $96 \mathrm{~h}$ (figure 1C). Inter-nucleosomal DNA fragmentation and Poly ADP Ribose Polymerase (PARP) cleavage were also observed in response to lovastatin (figure 2A, 2B). This apoptosis was strictly dependent on the activation of procaspases as the broad spectrum caspase inhibitor Z-VAD-fmk fully suppressed cell death. Furthermore, Z-VDVAD-fmk, a caspase-2 preferred inhibitor, reduced apoptosis by $86 \%$ and Z-DEVD-fmk, a caspase-(3/7) inhibitor, reduced apoptosis by $93 \%$ (figure $2 \mathrm{C}$ ). Hence, several caspases accounted for the high susceptibility of HGT-1 cells to lovastatin-dependent apoptosis. When assayed by overexpression, we found that caspase -7 had only a limited contribution to apoptosis induction (data not shown), suggesting that the strong inhibitory effect of Z-DEVD-fmk on lovastatin-induced apoptosis could be better explained by an effect on active caspase-3 than caspase-7. These results agree to the notion that the main mode of action of statins requires use of the intrinsic pathway of apoptosis and the activation of procaspases [7-9]. Hence, the death pathway activated by lovastatin in HGT-1 cells is likely apoptosis.

2) Intermediates of cholesterol synthesis prevent statin-induced cell death

Because statins prevent formation of mevalonate, we investigated the putative compensatory roles of mevalonate as well as farnesyl pyrophosphate (FPP), geranyl geranyl pyrophosphate (GGPP) and cholesterol, the end product of the pathway, on the apoptotic response to statins. We first analysed the amount of mevalonate and cholesterol in our cell culture medium (containing 5\% fetal calf serum). No mevalonate was detected (detection limit $1 \mu \mathrm{M}$ ), whereas $20 \mu \mathrm{M}$ cholesterol was determined. Hence, statin treatment was performed in absence of mevalonate, the product of HMG-CoA reductase activity. As shown in figure 3, all compounds reduced statin-dependent apoptosis. Added mevalonate, FPP and GGPP strongly reduced apoptosis for concentrations of $50 \mu \mathrm{M}$, even more so than cholesterol. In addition, GGPP was the strongest inhibitor of apoptosis, with a maximum activity for the concentration of $10 \mu \mathrm{M}$. Of note, partial compensation of the apoptotic activity of lovastatin was observed already for a concentration of added cholesterol of $10 \mu \mathrm{M}$, although the concentration of cholesterol in the culture medium was higher. This apparent discrepancy is likely due to the fact that the bioavailability of 
cholesterol in serum, which is essentially contained within lipoprotein particles, is much lower than that of purified cholesterol for HGT-1 cells. Taken together, these results suggest that target proteins that require prenylation (farnesylation, geranyl-geranylation), such as members of the Ras and Rho protein families, play important roles in the control of the apoptotic response in HGT-1-treated cells, like it has been demonstrated for other cell types $[22,23]$. It is possible that the protective effects brought about by cholesterol, on the one hand, and FPP or GGPP, on the other hand, depend on different mechanisms. Indeed, statins inhibit Rho cell signalling and this effect can be reversed by GGPP because GGPP provides a lipophilic anchor, which is essential for membrane attachment and biological activity of the Rho GTPases [24-26]. By contrast, cholesterol, as a major component of lipid rafts caveole, could help restore proper membrane architecture, which was likely to be altered by statins $[27,28]$.

\section{3) Caspase levels are modulated by statins}

\section{i) Lovastatin induces procaspase levels}

In order to determine the influence of statins on procaspases, western blot analyses were performed after $24 \mathrm{~h}$ of treatment with lovastatin in several cancer cell types. As shown in figure $4 \mathrm{~A}$, all procaspases surveyed showed slightly higher protein levels, not only in HGT-1 cells, but also in HCT116 colon cancer (except for procaspase-6) and $\mathrm{HepG}_{2}$ hepatoma cells. Procaspase-7 induction was the most marked in all cell lines, and was highest for HGT-1 cells. It has been reported that statins could also decrease expression of the anti-apoptotic Bcl-2 and survivin proteins [7, 29], an observation that we failed to make in this study in HGT-1 cells, suggesting that an increase in pro-apoptotic proteins, rather than a decrease in anti-apoptotic proteins was induced in response to lovastatin (data not shown). In addition, a dose-response experiment was performed in HGT-1 cells, which showed increased procaspase-7 levels for $5 \mu \mathrm{M}$ lovastatin, with a maximum between 25 and $50 \mu \mathrm{M}$ (figure 4B).

\section{ii) $C A S P-7$ is a $S R E B P 1 / 2$ responsive gene}

To determine if the inducibility of procaspases also occurred at the mRNA level, we assayed their expression by RT-PCR in response to lovastatin. However, no response was observed for caspases-3, 6 or 9, indicating that lovastatin was acting at the translational or post-translational levels for these caspases (data not shown). By contrast, caspase-7 mRNA was increased, albeit modestly (1.5 to 2-fold), by lovastatin following treatment with $50 \mu \mathrm{M}$ for $16 \mathrm{~h}$ (figure $5 \mathrm{~A}$ ). Analysis of caspase-7 mRNA stability by $\operatorname{DRB}(5,6$-dichlorobenzimidazole riboside) treatment $(80 \mu \mathrm{M})$ revealed that the mRNA half-life was relatively short (about 7h) and was not influenced by lovastatin, indicating that lovastatin did not act to stabilize the mRNA in a posttranscriptional fashion (data not shown). Translation inhibition by cycloheximide treatment led to a 2-fold induction of caspase-7 mRNA, an effect that was not influenced by lovastatin, suggesting that caspase- 7 mRNA level was under the control of a repressor protein (data not shown), which effect was not dependent on lovastatin. This was probably unrelated to nonsense-mediated mRNA decay since no prediction of a premature translational STOP codon could be made for caspase-7 transcripts [30]. Bioinformatics analyses showed that, among the caspase genes surveyed in this study, only the CASP-7 gene contained putative SREBP response elements (within the proximal $1.5 \mathrm{~kb}$ sequence upstream the transcriptional start site, MatInspector program at www.genomatix.de). In order to look for the involvement of SREBP transcription factors in the response to lovastatin, transient transfection experiments with the promoter region of the $C A S P-7$ gene were performed, which showed only a modest 
positive response to lovastatin or SREBP proteins (at most 1.5 -fold) in co-transfection experiments with plasmids encoding the transcriptionally active forms of the SREBP 1 or SREBP-2 proteins (data not shown). Although limited, this response was of the same magnitude as that observed at the mRNA level (figure 5A). As a more relevant approach to determine the putative role of SREBP-1 or 2 proteins on the endogenous CASP-7 gene, we performed chromatin immunoprecipitation (ChIP) analyses focussing on the proximal promoter region, which showed occurrence of 2 putative SREBP DNA binding sites. As shown in figure $5 \mathrm{~B}$, this promoter region of the CASP7 gene was able to bind SREBP proteins in live cells, suggesting that these may indeed participate in the regulation of the gene. Finally, we knocked down SREBP-1 or -2 mRNAs with specific siRNAs. As shown in figure 5C, a strong suppression of basal caspase- 7 mRNA was observed (45\% and 54\% decrease for SREBP-1 and SREBP-2 siRNAs, respectively). As a control, Fatty Acyl Synthase (FAS) gene expression, a known SREBP-1-response gene, was reduced by 34\% by SREBP-1 siRNAs (data not shown). In addition, Farnesyl pyrophosphate synthase (FPPS) and HMG-CoA reductase mRNAs, two recognized positive targets of SREBP-2, were also reduced, by $36 \%$ and $46 \%$ with SREBP-2 siRNAs, respectively (data not shown). Therefore, the CASP-7 gene is a true SREBP-1/2-responsive gene, and its basal expression level, i.e. in absence of statins, is positively controlled by SREBP-1/2. CASP-7 is the second caspase gene found to respond to SREBP proteins, as we have previously shown this to be the case for the $C A S P-2$ gene $[17,18]$. In addition, caspase-7 expression was decreased by roughly $30-40 \%$ with a 24 h treatment by cholesterol $(78 \mu \mathrm{M})$, in agreement with the control exerted by SREBP proteins over-expression on the gene (data not shown). Finally, preliminary evidence showed that silencing the S1P protein (a key component of the SREBP-response pathway) could also lead to a partial reduction of procaspase-7 protein levels in HGT-1 cells. The higher responsiveness of the procaspase-7 protein, as compared to the other procaspases, agrees to the notion that both transcriptional and post-transcriptional mechanisms occurred, making CASP7 a sensitive SREBP-dependent, lovastatin response gene. Finally, suppression of SREBP-1 and SREBP-2 protein with siRNAs also reduced procaspase-7 protein levels, but did not affect procaspase-9 used as a control (figure 5D). Furthermore, lovastatin responsiveness was partially maintained in presence of SREBP-1 and -2 siRNAs, in agreement with the fact that this induction of procaspase- 7 was afforded by both transcriptional and post-transcriptional mechanisms (figure 5E).

\section{6) Selection of statin resistant cells}

As an approach to derive statin-adapted cells, we grew HGT-1 cells in the continuous presence of $50 \mu \mathrm{M}$ lovastatin (see materials and methods). As stated above, no mevalonate was available to the cells as a compensatory metabolite. Hence, the selection procedure was performed under conditions where the pathway was blunted. As expected, a strong apoptotic mortality was observed initially but a few cells eventually emerged after 6 weeks and grew as novel populations (not cell clones since no limit dilution had been used), which we called L50 cells. Following culture in absence of statin for several cell doublings, no death occurred anymore upon re-addition of lovastatin, indicating phenotype stability. HGT-1-derived L50 cells displayed altered morphology with frequent cytoplasmic inclusions (figure 6A). In addition, the L50 cells had a slower growth rate than HGT-1 cells (figure 6B).

\section{7) Cell adaptation to lovastatin induces a remodelling in gene expression}


To further characterize these cells, several mRNA species were analysed by RT-PCR. As shown in figure 7A, L50 cells had higher HMG-CoA reductase mRNA levels than HGT1 , as may be expected since HMG-CoA reductase is the primary target of statins. Strikingly, caspase-7 mRNA was over-expressed in L50 cells, whereas caspase-9 and, to a lower extent, SREBP-1 mRNAs, were reduced. The procaspase-7 protein level was also higher in L50 cells, while procaspase-9 was decreased (figure 7B). In all individual HGT1 statin-resistant cell populations as well as in HCT116 statin-resistant colon cancer cells (supplementary figure), the level of procaspase-7 was increased as compared to that of the parental, statin-sensitive cells. Hence, expression of the CASP-7 gene was markedly increased in lovastatin resistant cell populations, an effect that was associated with higher levels of procaspase-7. We believe that the lovastatin treatment has selected, among the parental cell populations, those cells that already expressed higher caspase-7 levels, which may have helped overcome the deprivation of the biochemical species that were lacking when the mevalonate pathway was blunted.

ChIP assays showed that SREBP proteins were able to interact with the CASP-7 promoter in L50 cells as they did in HGT-1 cells (see figure 8A, which shows the same results for HGT-1 cells as figure 5B). Caspase-7 mRNA was suppressed in L50 cells upon transfection with SREBP-1 and -2 siRNAs, as occurred for HGT-1 cells (figure 8B). Furthermore, the level of procaspase-7 was also suppressed by siRNAs against SREBP-1 and/or SREBP-2 (figure 8C). Caspase-7 mRNA half-life was increased in L50 cells (about $10 \mathrm{~h}$ ) as compared to HGT-1 cells (about $7 \mathrm{~h}$ ), but was not influenced by lovastatin treatment, like in HGT-1 cells (data not shown). Finally, statin responsiveness was maintained in L50 cells (figure 8D). Hence, it appears that long term treatment of HGT-1 cells by lovastatin has selected cells with higher levels of procaspase-7, which may be due to increased transcription of the $C A S P-7$ gene or, more likely, to increased stability of caspase-7 mRNA, which resulted in increased levels of protein.

\section{CONCLUSION}

The present study identifies for the first time human $C A S P-7$ as a novel SREBP-1/2response gene, similarly to the $C A S P-2$ gene [18]. The two main aspects of this study are illustrated in figure 9. Upon short time treatment (16-24h), lovastatin could increase expression of caspase-7, mostly at the protein level (figure 9A), whereas SREBP proteins appeared to mainly control basal expression levels of the gene. Following long-term exposure (several weeks) to lovastatin, apoptosis-resistant cells were selected, and showed stably increased levels of both caspase-7 mRNA and protein (figure 9B). However, the apoptosis-inducing activity of lovastatin could be, at least in lovastatin-resistant cells, uncoupled from procaspase-7 inducibility since inducibility was maintained in L50 cells, and was not associated with a rise in DEVDase activity, indicating that the apoptotic machinery was not constitutively active in these cells (data not shown). Over-expression of caspase-7 in L50 cells may have represented a selective advantage for these cells, separate from apoptosis, when mevalonate shortage was imposed.

Caspase- 7 has often been considered as a surrogate to caspase- 3 in apoptosis since both caspases appear to act redundantly during the last steps of the suicide programme, and caspase- 7 expression could be increased in cells deficient in caspase-3 [31, 32]. Yet, CASP-3 KO mice showed several abnormalities, including neuroepithelial progenitor dysfunction, but survived with some degree of perinatal lethality on the 129 genetic background. By contrast, CASP-7 KO mice were fully viable and healthy on the same background, strongly suggesting that these caspases are not fully redundant[33, 34]. In addition, caspase- 3 and caspase- 7 have partially distinct substrate specificity, as shown by a degradomic approach[35] and by substrate cleavage analysis[36]. Thus, the functions of 
caspase-7 are unlikely to be fully interchangeable. The present results show that their response to lovastatin, and expression in L50 cells were different, which also suggests differential regulation and, possibly, function.

It is worthy of note that L50 cells characterized here grew more slowly than HGT-1 cells. How slower cell growth could be related to the over expression of caspase-7 will require further analyses. We are currently addressing the possibility that caspase- 7 may play a role in protein prenylation. Indeed, HGT-1 cells do not carry K-Ras codon 12 or 13 mutations, the most frequent Ras mutations (data not shown), indicating that the signal pathway activated by Ras is functional in these cells, and may be blunted by statins, or by adaptation to statins.

No additional caspase gene was found to respond to lovastatin, nor was predicted to be able to do so since no putative SREBP binding sites were found by bioinformatics analysis (data not shown). Contrary to caspase-2 [18], we did not obtain any evidence that caspase-7 could exert a positive control on cholesterol levels in HGT-1 cells. Nevertheless, our results suggest that caspase-7, as a SREBP target, may bear a novel, unreported biological activity, beyond execution of apoptosis, which may further exemplify the fact that caspases can participate in cell death unrelated functions [37].

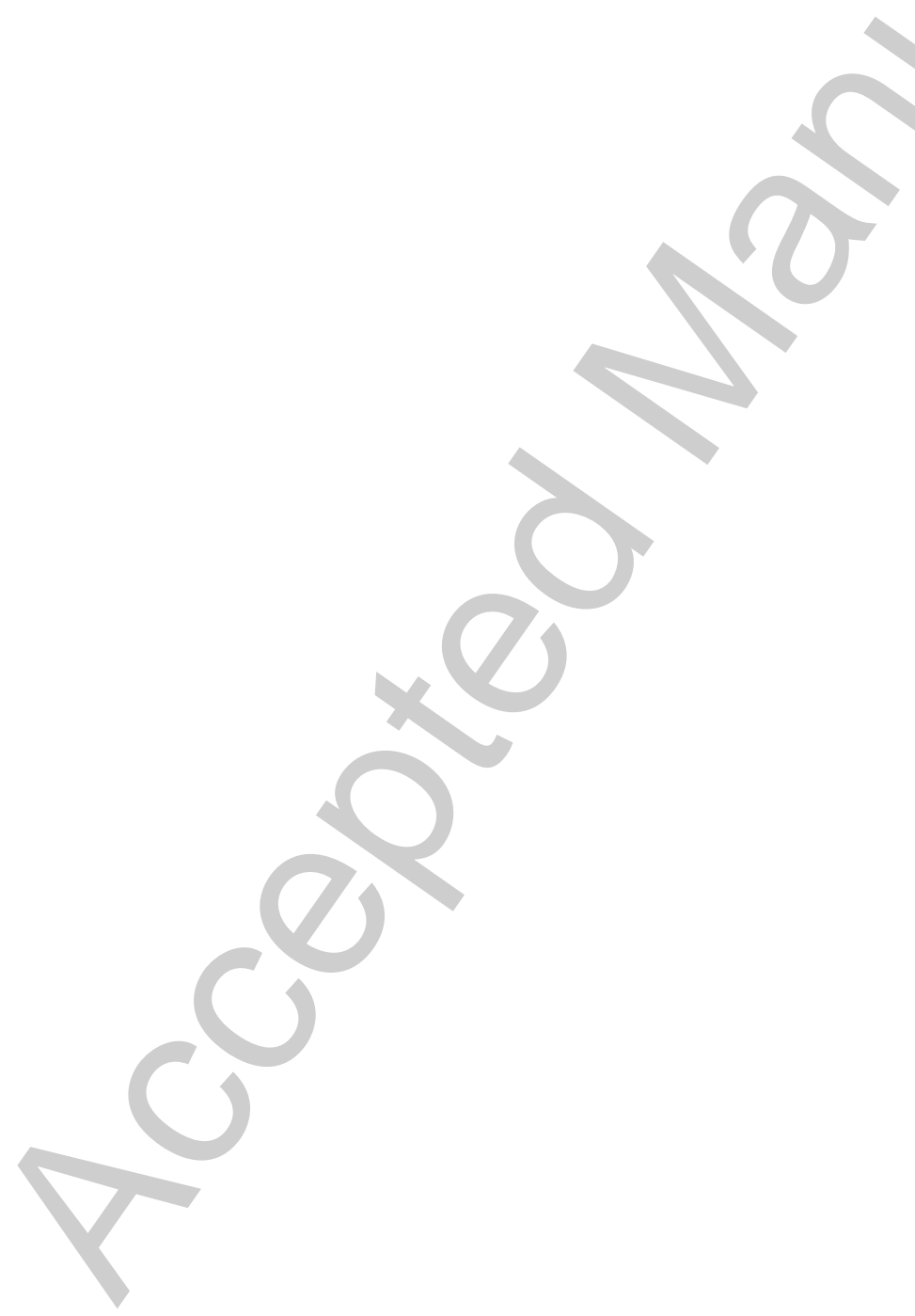




\section{ACKNOWLEDGEMENTS}

L. Gibot was supported by a grant from the Agrocampus (Rennes, France), J. Follet was a recipient from the Conseil Régional de Bretagne. We wish to thank Dr C. Laboisse for his gift of HGT-1 cells and Drs L. Henneman and H. Waterham for the mevalonate determination assays. This work was supported by the INSERM, the Cancéropôle Grand Ouest, the Ligue contre le Cancer (committees of Finistère, Côtes d'Armor and Cher), the FEDER funds, the Brittany Region, the CRITT Santé Bretagne, the University of Brest, the Medical Faculty, the University Hospital of Brest and the Ministry of Research and Education. 


\section{REFERENCES}

1 Wong, W. W., Dimitroulakos, J., Minden, M. D. and Penn, L. Z. (2002) HMG-CoA reductase inhibitors and the malignant cell: the statin family of drugs as triggers of tumor-specific apoptosis. Leukemia 16, 508-519

2 Mo, H. and Elson, C. E. (2004) Studies of the isoprenoid-mediated inhibition of mevalonate synthesis applied to cancer chemotherapy and chemoprevention. Exp Biol Med (Maywood) 229, 567-585

3 Fritz, G. (2005) HMG-CoA reductase inhibitors (statins) as anticancer drugs (review). Int J Oncol 27, 1401-1409

4 Demierre, M. F., Higgins, P. D., Gruber, S. B., Hawk, E. and Lippman, S. M. (2005) Statins and cancer prevention. Nat Rev Cancer 5, 930-942

5 Katz, M. S. (2005) Therapy insight: Potential of statins for cancer chemoprevention and therapy. Nat Clin Pract Oncol 2, 82-89

6 Narisawa, T., Fukaura, Y., Tanida, N., Hasebe, M., Ito, M. and Aizawa, R. (1996) Chemopreventive efficacy of low dose of pravastatin, an HMG-CoA reductase inhibitor, on 1,2-dimethylhydrazine-induced colon carcinogenesis in ICR mice. Tohoku J Exp Med 180, 131-138

7 Kaneko, R., Tsuji, N., Asanuma, K., Tanabe, H., Kobayashi, D. and Watanabe, N. (2007) Survivin down-regulation plays a crucial role in 3-hydroxy-3-methylglutaryl coenzyme A reductase inhibitor-induced apoptosis in cancer. J Biol Chem 282, 1927319281

8 Wang, J., Xu, Z. and Zhang, M. (2007) Downregulation of survivin expression and elevation of caspase-3 activity involved in pitavastatin-induced HepG 2 cell apoptosis. Oncol Rep 18, 383-387

9 Cafforio, P., Dammacco, F., Gernone, A. and Silvestris, F. (2005) Statins activate the mitochondrial pathway of apoptosis in human lymphoblasts and myeloma cells. Carcinogenesis 26, 883-891

10 Xia, Z., Tan, M. M., Wong, W. W., Dimitroulakos, J., Minden, M. D. and Penn, L. Z. (2001) Blocking protein geranylgeranylation is essential for lovastatin-induced apoptosis of human acute myeloid leukemia cells. Leukemia 15, 1398-1407

11 Gouni-Berthold, I., Berthold, H. K., Gylling, H., Hallikainen, M., Giannakidou, E., Stier, S., Ko, Y., Patel, D., Soutar, A. K., Seedorf, U., Mantzoros, C. S., Plat, J. and Krone, W. (2008) Effects of ezetimibe and/or simvastatin on LDL receptor protein expression and on LDL receptor and HMG-CoA reductase gene expression: a randomized trial in healthy men. Atherosclerosis 198, 198-207

12 Funatsu, T., Suzuki, K., Goto, M., Arai, Y., Kakuta, H., Tanaka, H., Yasuda, S., Ida, M., Nishijima, S. and Miyata, K. (2001) Prolonged inhibition of cholesterol synthesis by atorvastatin inhibits apo B-100 and triglyceride secretion from HepG2 cells. Atherosclerosis 157, 107-115

13 Brown, A. J., Sun, L., Feramisco, J. D., Brown, M. S. and Goldstein, J. L. (2002) Cholesterol addition to ER membranes alters conformation of SCAP, the SREBP escort protein that regulates cholesterol metabolism. Mol Cell 10, 237-245

14 Edwards, P. A., Tabor, D., Kast, H. R. and Venkateswaran, A. (2000) Regulation of gene expression by SREBP and SCAP. Biochim Biophys Acta 1529, 103-113

15 Horton, J. D., Goldstein, J. L. and Brown, M. S. (2002) SREBPs: activators of the complete program of cholesterol and fatty acid synthesis in the liver. J Clin Invest 109, 1125-1131

16 Horton, J. D., Shah, N. A., Warrington, J. A., Anderson, N. N., Park, S. W., Brown, M. S. and Goldstein, J. L. (2003) Combined analysis of oligonucleotide microarray 
data from transgenic and knockout mice identifies direct SREBP target genes. Proc Natl Acad Sci U S A 100, 12027-12032

17 Logette, E., Solary, E. and Corcos, L. (2005) Identification of a functional DNA binding site for the SREBP-1c transcription factor in the first intron of the human caspase-2 gene. Biochim Biophys Acta 1738, 1-5

18 Logette, E., Le Jossic-Corcos, C., Masson, D., Solier, S., Sequeira-Legrand, A., Dugail, I., Lemaire-Ewing, S., Desoche, L., Solary, E. and Corcos, L. (2005) Caspase2 , a novel lipid sensor under the control of sterol regulatory element binding protein 2 . Mol Cell Biol 25, 9621-9631

19 Laboisse, C. L., Augeron, C., Couturier-Turpin, M. H., Gespach, C., Cheret, A. M. and Potet, F. (1982) Characterization of a newly established human gastric cancer cell line HGT-1 bearing histamine H2-receptors. Cancer Res 42, 1541-1548

20 Henneman, L., van Cruchten, A. G., Denis, S. W., Amolins, M. W., Placzek, A. T., Gibbs, R. A., Kulik, W. and Waterham, H. R. (2008) Detection of nonsterol isoprenoids by HPLC-MS/MS. Anal Biochem

21 Sivaprasad, U., Abbas, T. and Dutta, A. (2006) Differential efficacy of 3-hydroxy-3methylglutaryl CoA reductase inhibitors on the cell cycle of prostate cancer cells. Mol Cancer Ther 5, 2310-2316

22 Fritz, G. and Kaina, B. (2006) Rho GTPases: promising cellular targets for novel anticancer drugs. Curr Cancer Drug Targets 6, 1-14

23 Fromigue, O., Hay, E., Modrowski, D., Bouvet, S., Jacquel, A., Auberger, P. and Marie, P. J. (2006) RhoA GTPase inactivation by statins induces osteosarcoma cell apoptosis by inhibiting p42/p44-MAPKs-Bc1-2 signaling independently of BMP-2 and cell differentiation. Cell Death Differ 13, 1845-1856

24 Seabra, M. C. (1998) Membrane association and targeting of prenylated Ras-like GTPases. Cell Signal 10, 167-172

25 Malaney, S. and Daly, R. J. (2001) The ras signaling pathway in mammary tumorigenesis and metastasis. J Mammary Gland Biol Neoplasia 6, 101-113

26 Sahai, E. and Marshall, C. J. (2002) RHO-GTPases and cancer. Nat Rev Cancer 2, 133-142

27 Fielding, C. J. and Fielding, P. E. (2000) Cholesterol and caveolae: structural and functional relationships. Biochim Biophys Acta 1529, 210-222

28 Zhuang, L., Kim, J., Adam, R. M., Solomon, K. R. and Freeman, M. R. (2005) Cholesterol targeting alters lipid raft composition and cell survival in prostate cancer cells and xenografts. J Clin Invest 115, 959-968

29 Blanco-Colio, L. M., Villa, A., Ortego, M., Hernandez-Presa, M. A., Pascual, A., Plaza, J. J. and Egido, J. (2002) 3-Hydroxy-3-methyl-glutaryl coenzyme A reductase inhibitors, atorvastatin and simvastatin, induce apoptosis of vascular smooth muscle cells by downregulation of Bcl-2 expression and Rho A prenylation. Atherosclerosis 161, 17-26

30 Solier, S., Logette, E., Desoche, L., Solary, E. and Corcos, L. (2005) Nonsensemediated mRNA decay among human caspases: the caspase-2S putative protein is encoded by an extremely short-lived mRNA. Cell Death Differ 12, 687-689

31 Fernandes-Alnemri, T., Litwack, G. and Alnemri, E. S. (1995) Mch2, a new member of the apoptotic Ced-3/Ice cysteine protease gene family. Cancer Res 55, 2737-2742

32 Talanian, R. V., Quinlan, C., Trautz, S., Hackett, M. C., Mankovich, J. A., Banach, D., Ghayur, T., Brady, K. D. and Wong, W. W. (1997) Substrate specificities of caspase family proteases. J Biol Chem 272, 9677-9682 
33 Kuida, K., Zheng, T. S., Na, S., Kuan, C., Yang, D., Karasuyama, H., Rakic, P. and Flavell, R. A. (1996) Decreased apoptosis in the brain and premature lethality in CPP32-deficient mice. Nature 384, 368-372

34 Lakhani, S. A., Masud, A., Kuida, K., Porter, G. A., Jr., Booth, C. J., Mehal, W. Z., Inayat, I. and Flavell, R. A. (2006) Caspases 3 and 7: key mediators of mitochondrial events of apoptosis. Science 311, 847-851

35 Jang, M., Park, B. C., Kang, S., Lee do, H., Cho, S., Lee, S. C., Bae, K. H. and Park, S. G. (2008) Mining of caspase-7 substrates using a degradomic approach. Mol Cells 26, $152-157$

36 Walsh, J. G., Cullen, S. P., Sheridan, C., Luthi, A. U., Gerner, C. and Martin, S. J. (2008) Executioner caspase-3 and caspase-7 are functionally distinct proteases. Proc Natl Acad Sci U S A 105, 12815-12819

37 Launay, S., Hermine, O., Fontenay, M., Kroemer, G., Solary, E. and Garrido, C. (2005) Vital functions for lethal caspases. Oncogene 24, 5137-5148 


\section{FIGURE LEGENDS}

\section{Figure 1}

Apoptosis induction by statins in HGT-1 gastric cancer cells.

(A) Statins were used at 25 and $50 \mu \mathrm{M}$ for $48 \mathrm{~h}$. Apoptosis was determined by Hoechst 33342 staining. Values are means \pm S.D. from four experiments. *: Statistically different from control $(\mathrm{p}<0.01)$ (Student's $t$ test). (B) Caspase $3 / 7$ activity (caspase Glo ${ }^{\mathrm{TM}} 3 / 7$ assay) was determined after $36 \mathrm{~h}$ for $25 \mu \mathrm{M}$ statin. The results are from one experiment among two with similar results. Values are means \pm S.D. of three wells. (C) Dose-response and time-course analysis of lovastatin-induced apoptosis. The results are from three experiments (means $\pm \mathrm{SD}$ are shown).

\section{Figure 2}

Apoptosis characteristics in lovastatin-treated cells

(A) DNA fragmentation in HGT-1 cells incubated with different concentrations of lovastatin for 96 h. Genomic DNA was extracted and analysed with 1.8\% agarose gels. (B) Poly ADP Ribose Polymerase (PARP) cleavage was analysed by western blotting after $48 \mathrm{~h}$ of treatment. Camptothecin (Cpt, 48h) was used as a positive control for apoptosis induction. Hsc70 was used as a loading control. The results are from one experiment among two with similar results. (C) Effect of caspase inhibitors on lovastatin-dependent cell death. Inhibitors were used at $100 \mu \mathrm{M}$ and were added together with lovastatin $(50 \mu \mathrm{M})$ for $48 \mathrm{~h}$. Apoptosis was determined by Hoechst 33342 staining. Values are means \pm S.D. ( $n=4)$. *: Statistically different from control $(\mathrm{p}<0.01)$ (Student's $t$ test).

\section{Figure 3}

Effect of mevalonate pathway intermediates and cholesterol on lovastatin-dependent apoptosis.

Cells were treated with various concentrations of the compounds in presence of $50 \mu \mathrm{M}$ lovastatin for $48 \mathrm{~h}$. Apoptosis was determined by Hoechst 33342 staining. Values are means \pm S.D. $(\mathrm{n}=4)$. *: Statistically different from control $(\mathrm{p}<0.01)$ (Student's $t$ test).

\section{Figure 4}

Procaspase levels in three human cancer cell lines in response to lovastatin.

(A) Procaspase protein levels were determined by western blotting analysis following treatment with $50 \mu \mathrm{M}$ lovastatin for $24 \mathrm{~h}$. Hsc70 was used as a loading control. The results were from one experiment among four (HGT-1) or two (HCT116, HepG2) with similar results. ${ }^{\text {a: }}$ Statistically different from control $(\mathrm{p}<0.05)$ (Student's $t$ test). (B) Dose-response of lovastatin on the level of procaspase-7 analysed by western blotting in HGT-1 cells. Hsc70 was used as a loading control. Results are from one experiment among three with similar results.

\section{Figure 5}

Caspase-7 mRNA level in response to lovastatin, ChIP analysis and effects of SREBP-1 and -2 siRNAs in HGT- 1 cells.

(A) Caspase-7 mRNA levels were determined by RT-PCR with RNA from HGT-1 cells treated for $16 \mathrm{~h}$ with $50 \mu \mathrm{M}$ lovastatin. P0 mRNA was used as an invariant control. (B) ChIP analysis of the proximal CASP-7 gene promoter region in HGT-1 cells. A 360 bp CASP-7 genomic DNA fragment was analysed by PCR, following chromatin immunoprecipitation of SREBP-DNA complexes, with specific primers (see materials and methods). The data are representative from three independent experiments with similar results. (C) Effect of SREBP- 
1 and -2 silencing on Caspase-7 levels. HGT-1 cells were transfected (see materials and methods) with siRNAs against SREBP-1 (siSREBP-1), SREBP-2 (siSREBP-2), or Caspase-7 (siCasp7) and compared to the negative control (siNeg). mRNA levels (determined by RTPCR) were standardized to P0 levels, which was used as a invariant control. Values represent the mean of 4 independent experiments \pm S.D. *: Statistically different from siNeg control $(\mathrm{p}<0.01)$ (Student's $t$ test). (D, E) Procaspase protein levels were analysed by western blotting with total cell extracts from siRNA-treated cells in absence (D) or presence (E) of $50 \mu \mathrm{M}$ lovastatin for $30 \mathrm{~h}$. Hsc70 was used as an invariant control. SREBP-1 and -2 protein levels following mRNA silencing were determined with specific anti-SREBP antibodies (see materials and methods).

\section{Figure 6}

\section{Morphology and growth of statin-sensitive and statin-resistant cells.}

(A) HGT-1 and L50 cells morphology. Photomicrographs of HGT-1 and lovastatin resistant derivatives L50 cells (x20, same magnification for both cell lines), from cultures (L50 cells) in absence of lovastatin for several cell doublings. (B) Growth curves of HGT-1 and L50 cells in normal medium. The results are from three experiments. Each time-point is the mean of three determinations performed on duplicate wells.

\section{Figure 7}

\section{Gene expression levels in HGT-1 and L50 cells}

(A) RNA levels were analysed by RT-PCR (see materials and methods). The two bands detected for Caspase-9 mRNA correspond to alternatively spliced transcripts. The results are from one experiment among five with similar results. : Statistically different from control $(\mathrm{p}<0.05),{ }^{\mathrm{b}}:(\mathrm{p}<0.01)$ (Student's $t$ test). (B) Western blot analysis of procaspase proteins in HGT-1 and L50 cells. The results are from one experiment among four with similar results. ${ }^{\text {a }}$ : Statistically different from control $(\mathrm{p}<0.05),{ }^{\mathrm{b}}:(\mathrm{p}<0.01)$ (Student's $t$ test).

\section{Figure 8}

\section{SREBP control of $C A S P-7$ gene expression in statin-resistant cells}

(A) ChIP analysis of the proximal CASP-7 gene promoter region in HGT-1 and L50 cells (see legend to figure 5B). (B) Effect of SREBP-1 and SREBP-2 siRNAs in L50 cells. Caspase-7 mRNA level was determined by RT-PCR following transfection with siRNAs, as indicated. The results are from three independent experiments. *: Statistically different from siNeg $(\mathrm{p}<0.01)$ (Student's $t$ test). (C) Effect of SREBP-1 and SREBP-2 siRNAs on protein levels in L50 cells. Results are from one experiment among three with similar results. SREBP-1 and -2 silencing was determined with specific anti-SREBP antibodies (see materials and methods). (D) Effect of lovastatin on procaspase-3 and -7 protein levels in L50 cells. Cells were treated with $50 \mu \mathrm{M}$ lovastatin for $16 \mathrm{~h}$. The results are from one experiment among four with similar results. ${ }^{\text {a }}$ : Statistically different from control $(\mathrm{p}<0.05)$ (Student's $t$ test).

\section{Figure 9}

\section{Summary of the main aspects of this study}

Two distinct situations were observed. When HGT-1 cells were treated with lovastatin for 16$24 \mathrm{~h}$, caspase-7 mRNA and protein were increased, presumably through both mRNA stabilization and increased translation and/or protein stabilisation, whereas transcriptional activation was modest (A). When the cells were treated for several weeks with lovastatin, apoptosis-resistant cells were selected, which showed increased amounts of caspase-7 mRNA and protein (B). 
A

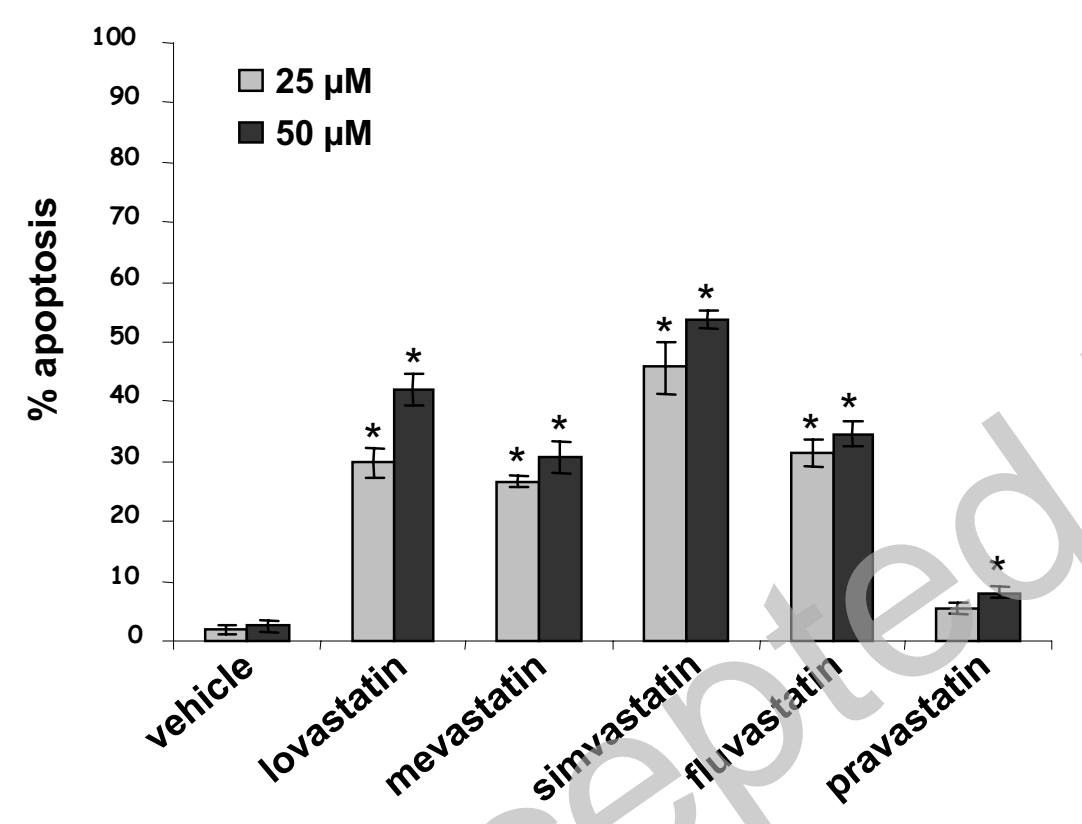

B

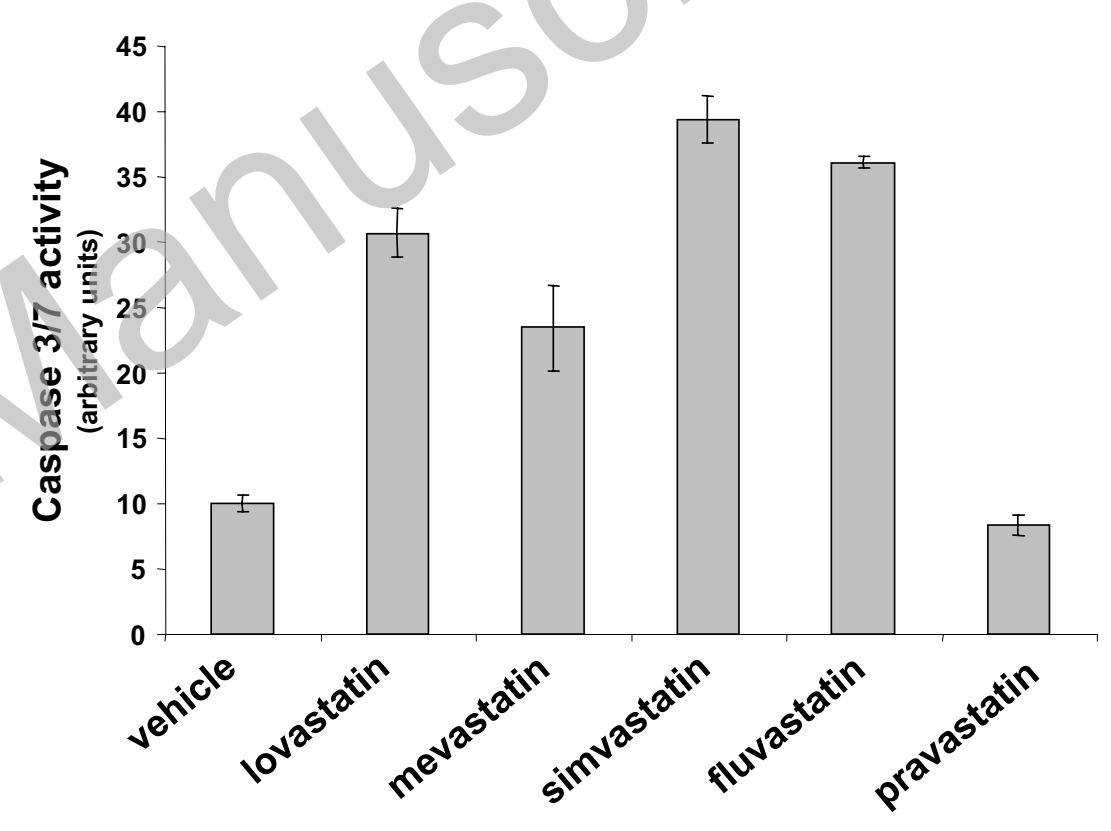

\section{Figure 1}

Licenced copy. Copying is not permitted, except with prior permission and as allowed by law. (c) 2009 The Authors Journal compilation (@ 2009 Portland Press Limited 
C

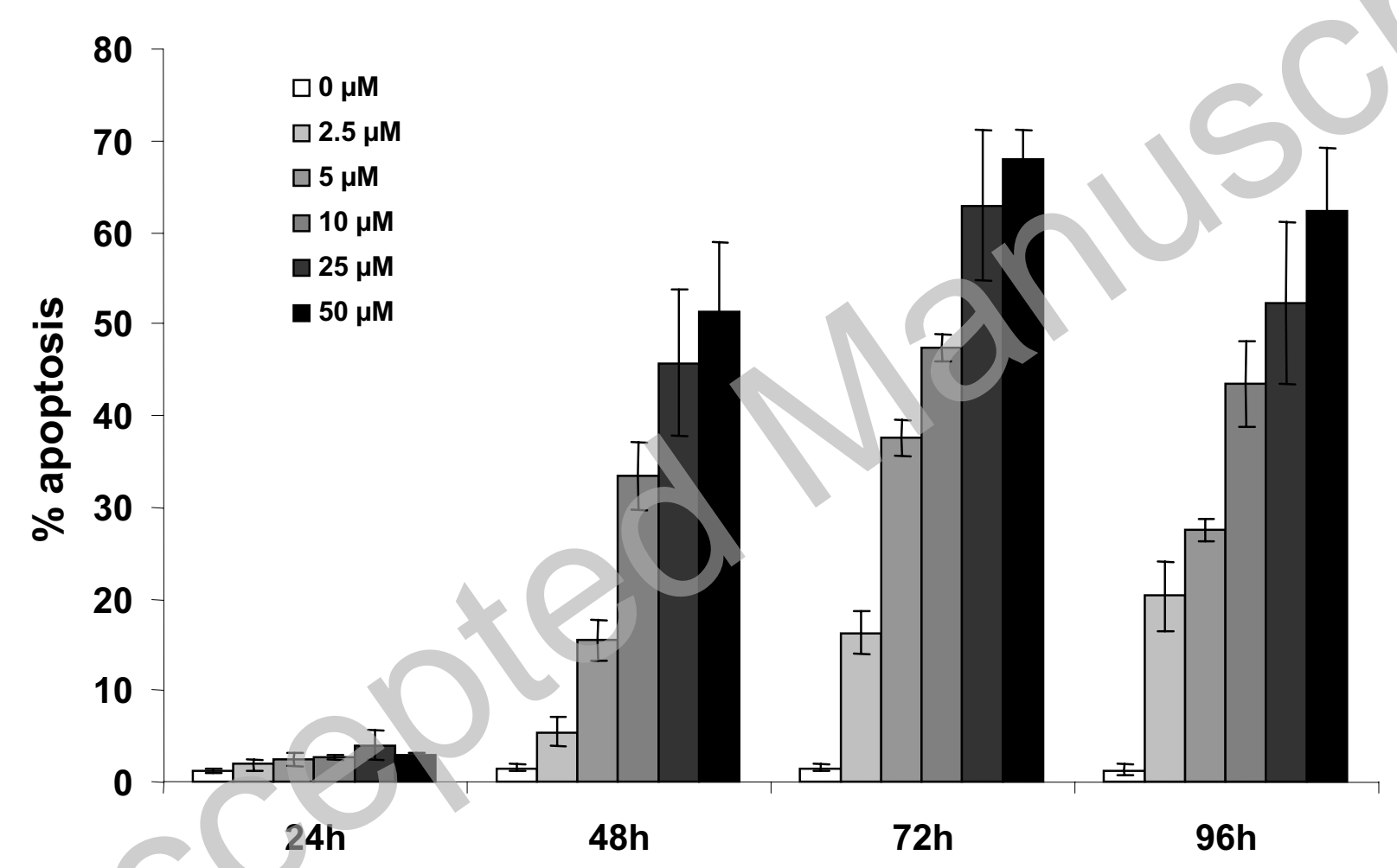

Figure 1

Licenced copy. Copying is not permitted, except with prior permission and as allowed by law.

(c) 2009 The Authors Journal compilation @ 2009 Portland Press Limited 
A

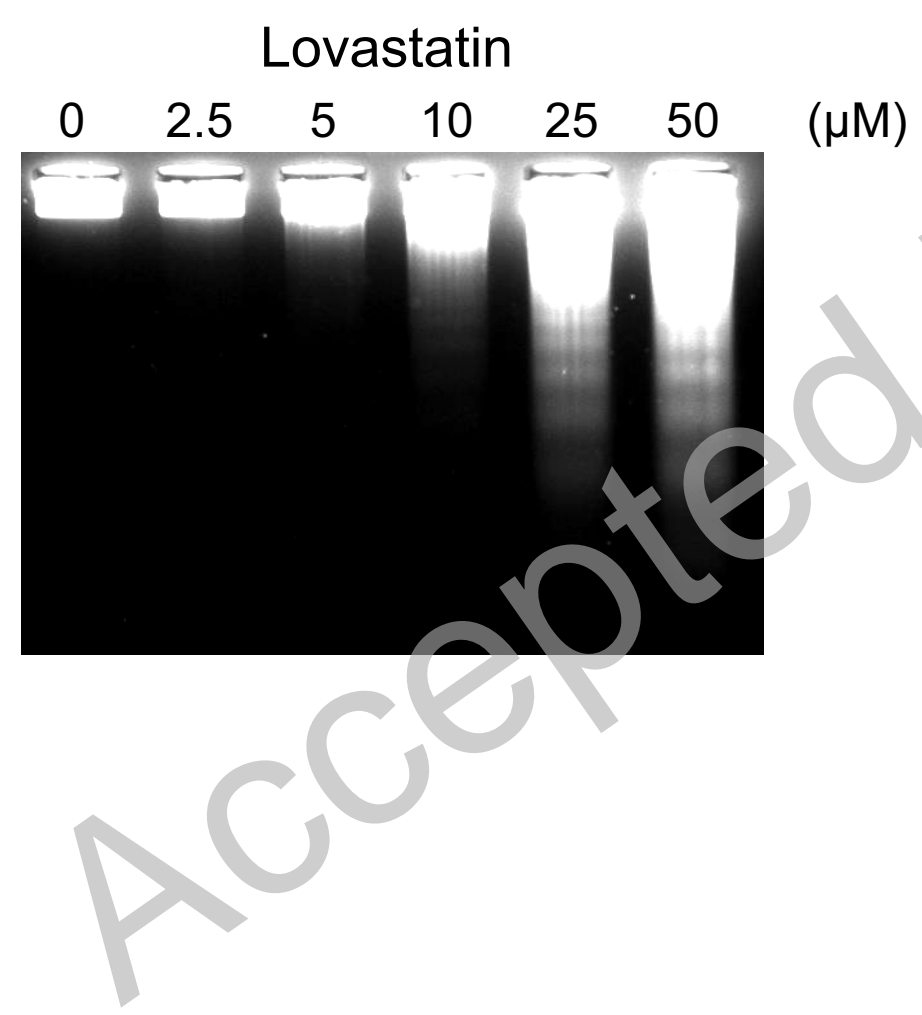

B Lovastatin $\mathrm{Cpt}$

$\begin{array}{lllll}0 & 25 & 50 & 2 & (\mu \mathrm{M})\end{array}$

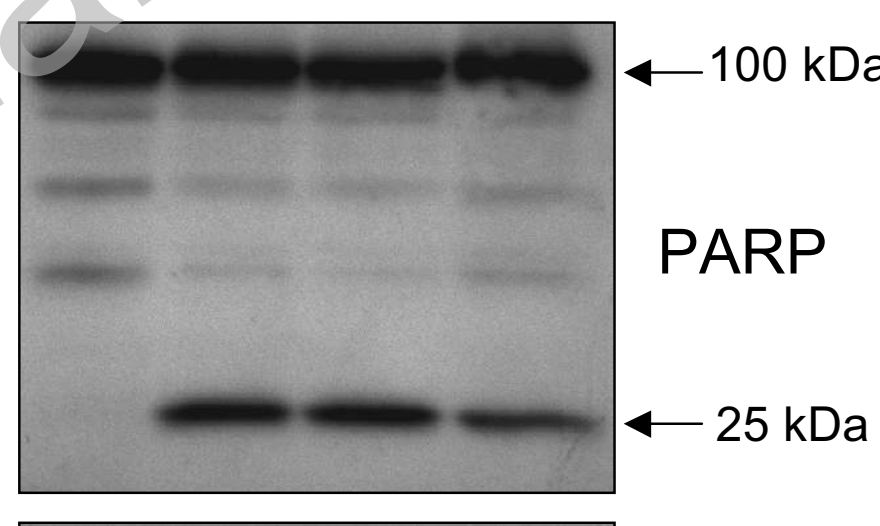

Hsc70

\section{Figure 2}

Licenced copy. Copying is not permitted, except with prior permission and as allowed by law. (c) 2009 The Authors Journal compilation @ 2009 Portland Press Limited 


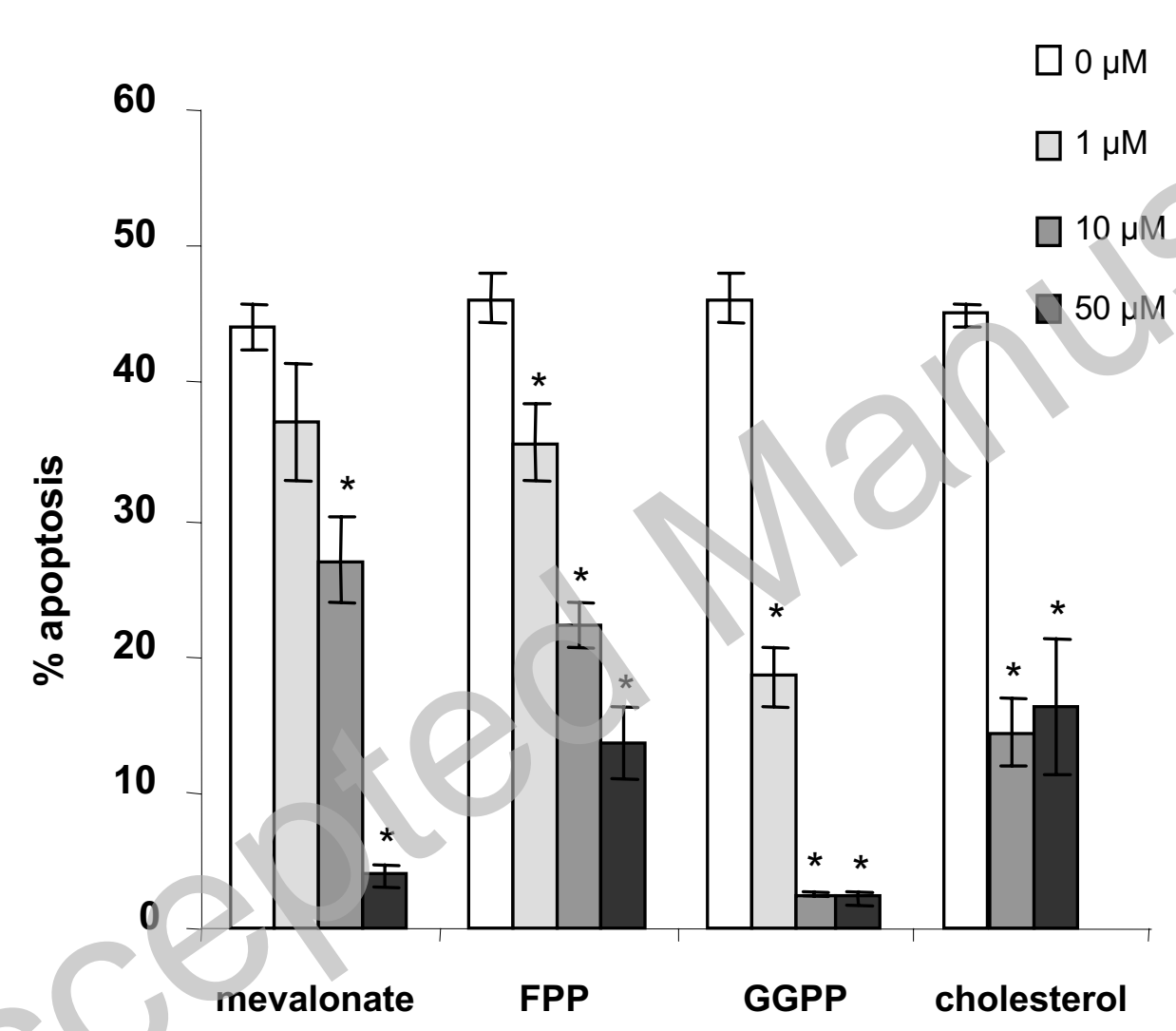

Figure 3

Licenced copy. Copying is not permitted, except with prior permission and as allowed by law. (c) 2009 The Authors Journal compilation @ 2009 Portland Press Limited 
A

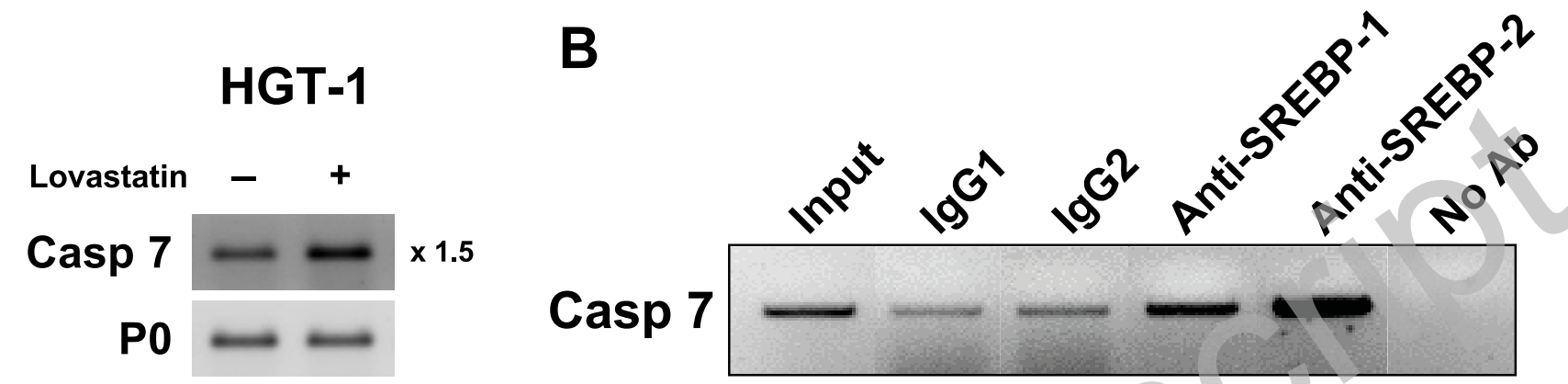

C

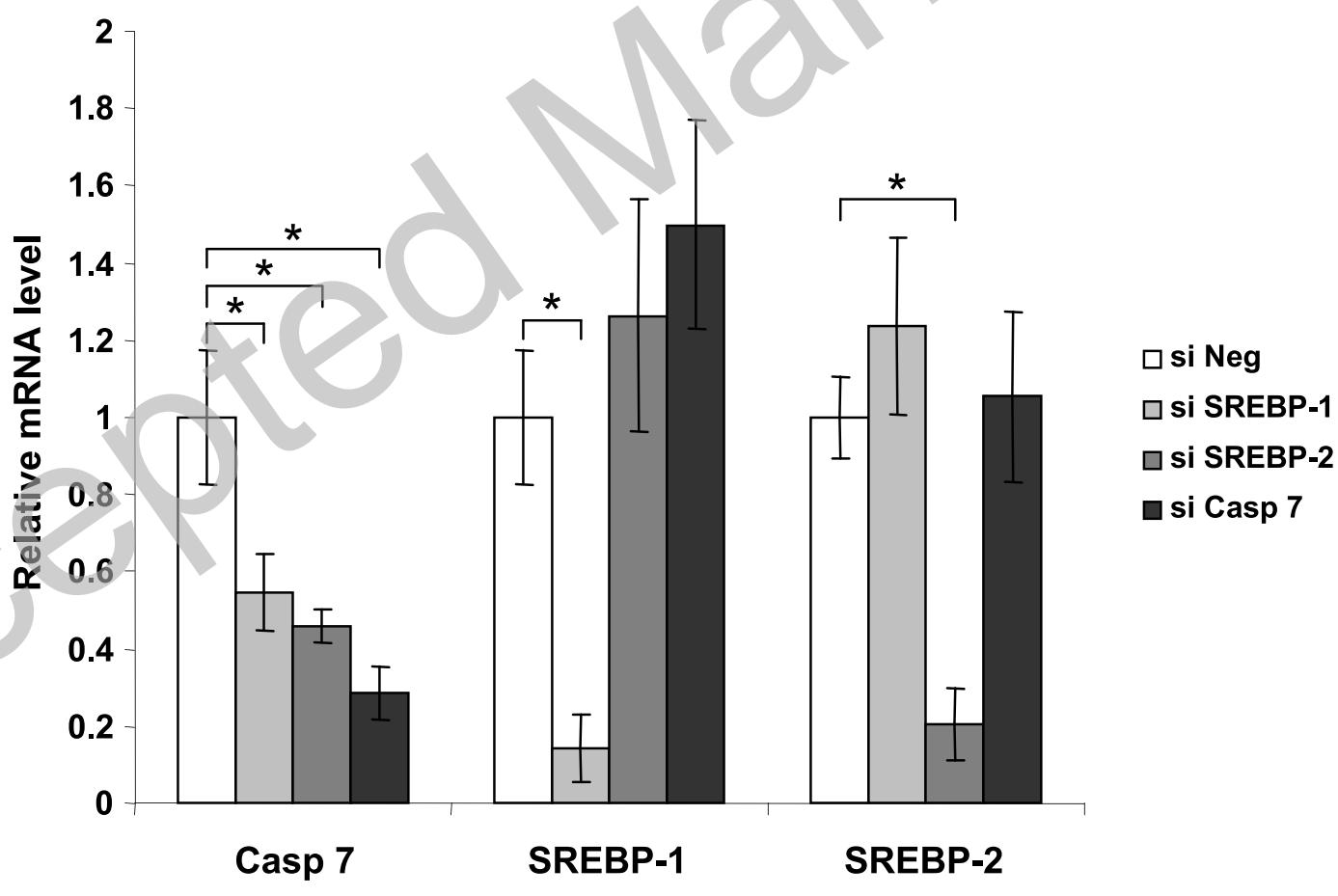

\section{Figure 5}

Licenced copy. Copying is not permitted, except with prior permission and as allowed by law. (c) 2009 The Authors Journal compilation @ 2009 Portland Press Limited 
B Biochemical Journal Immediate Publication. Published on 25 Mar 2009 as manuscript BJ20082057

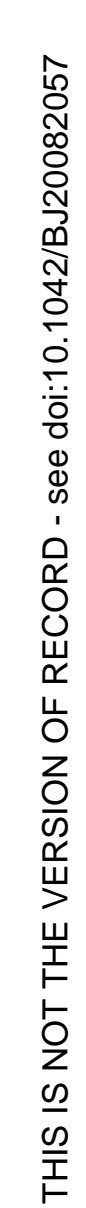

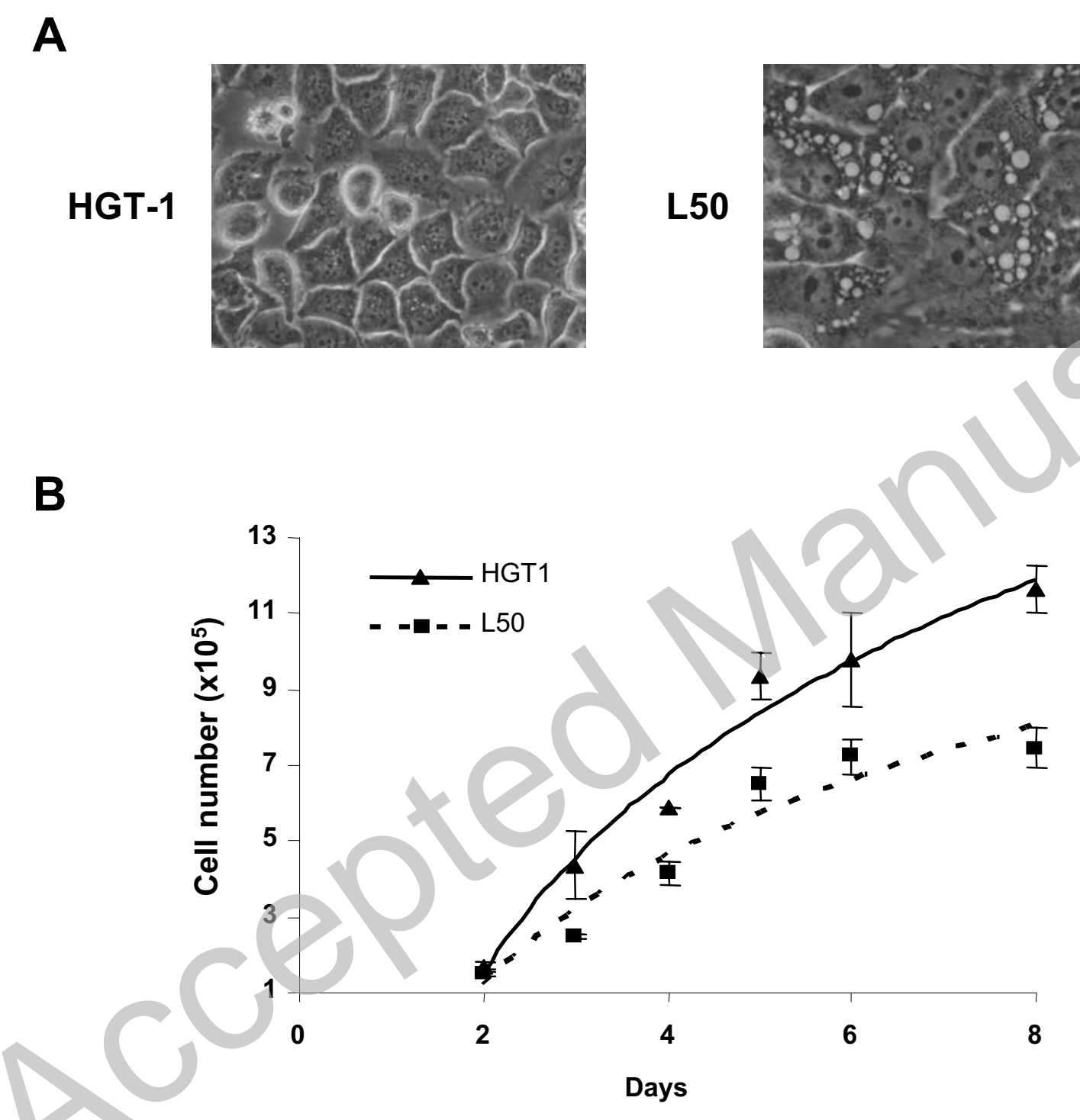

\section{Figure 6}

Licenced copy. Copying is not permitted, except with prior permission and as allowed by law.

(C) 2009 The Authors Journal compilation (@ 2009 Portland Press Limited 


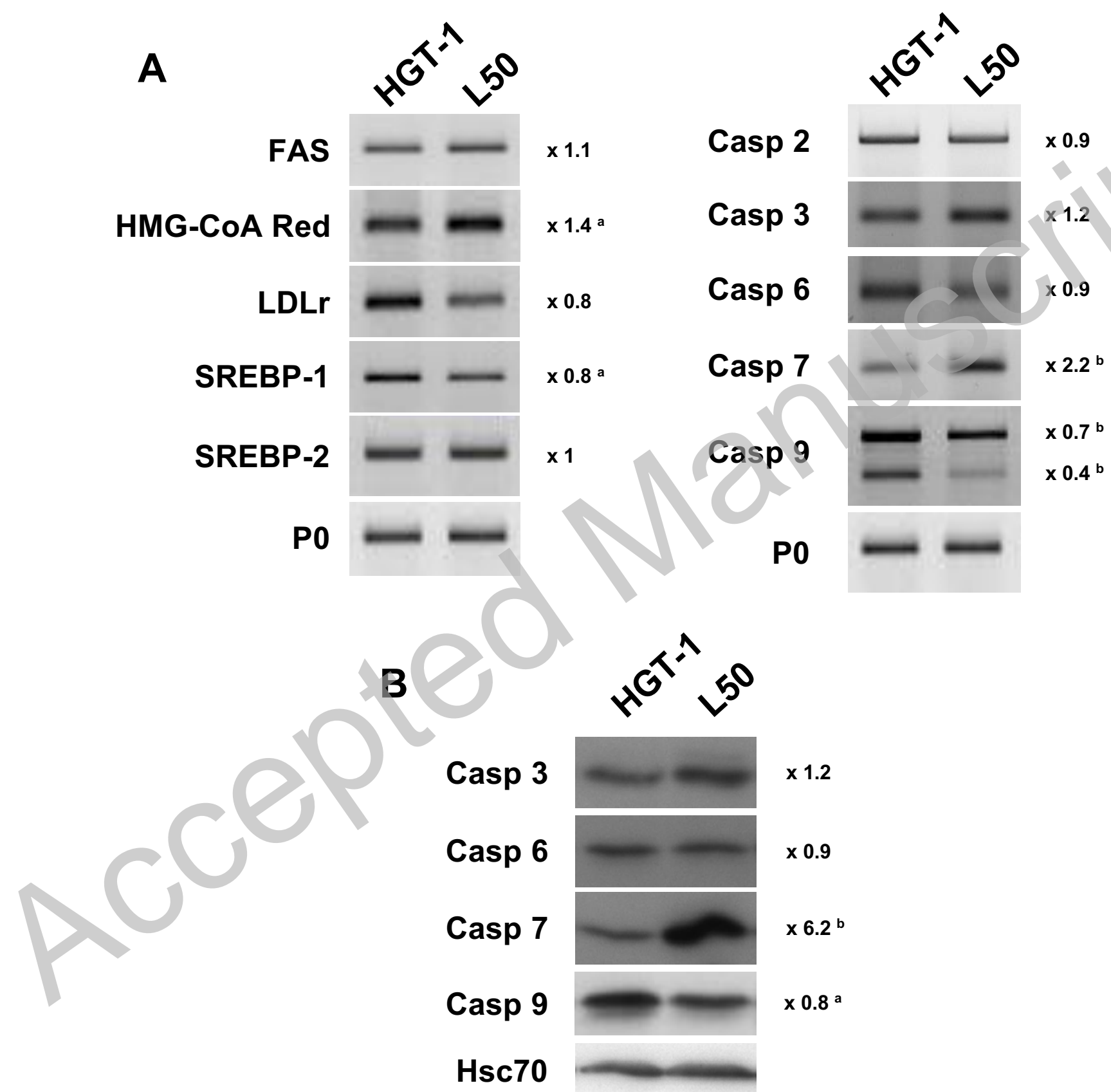

\section{Figure 7}

Licenced copy. Copying is not permitted, except with prior permission and as allowed by law. (c) 2009 The Authors Journal compilation ( 2009 Portland Press Limited 


\section{B Biochemical Journal Immediate Publication. Published on 25 Mar 2009 as manuscript BJ20082057}

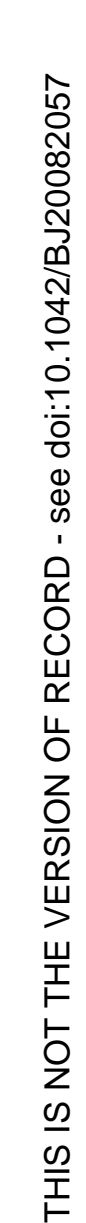

C

siRNA : $\quad$ Neg $\quad$ Casp7 $\quad$ SREBP-1 SREBP-2

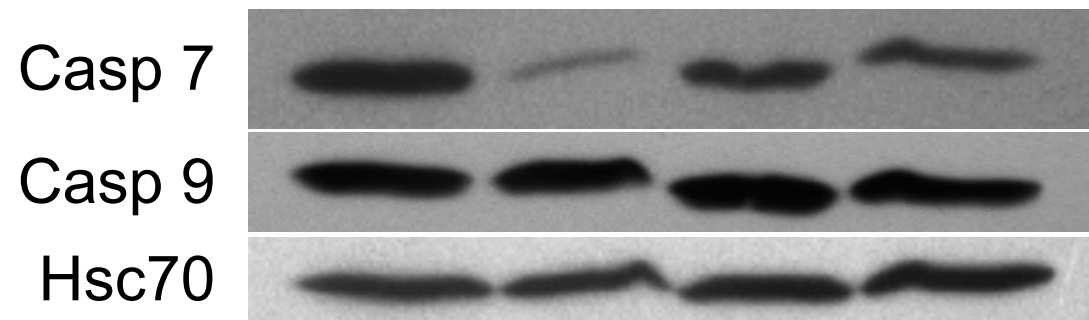

siRNA: Neg SREBP-1 siRNA: Neg SREBP-2

SREBP-1

HSC70

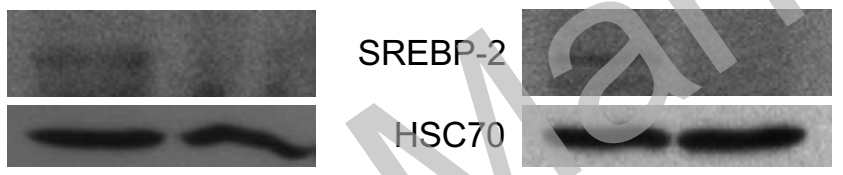

D
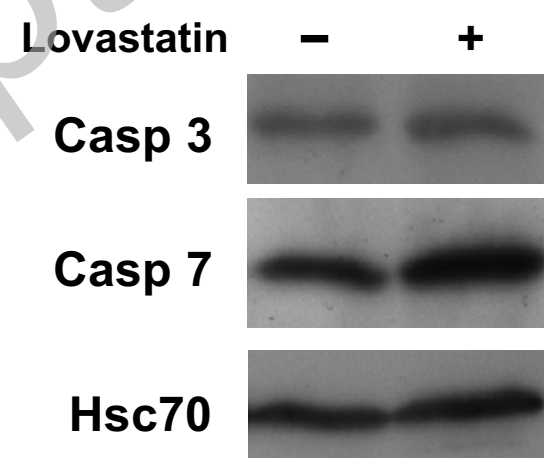

$\mathbf{x} 1.2$

$\times 2.2^{a}$

Figure 8

Licenced copy. Copying is not permitted, except with prior permission and as allowed by law. (c) 2009 The Authors Journal compilation (@ 2009 Portland Press Limited 
A

Short treatment with lovastatin
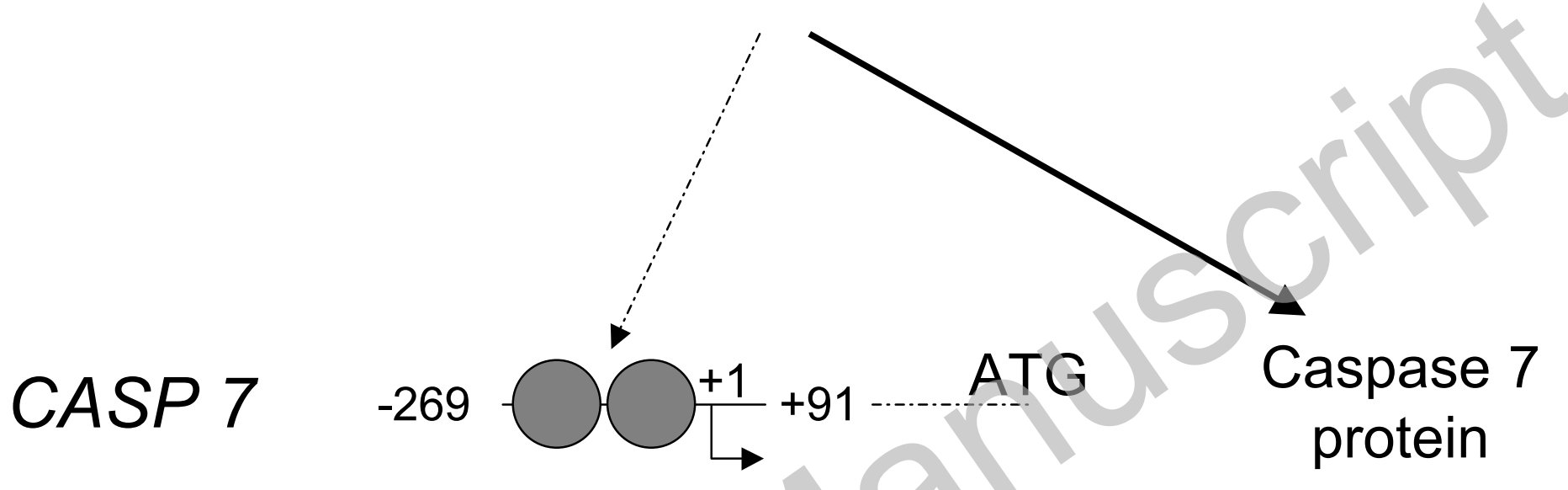

SREBP-1/2

B

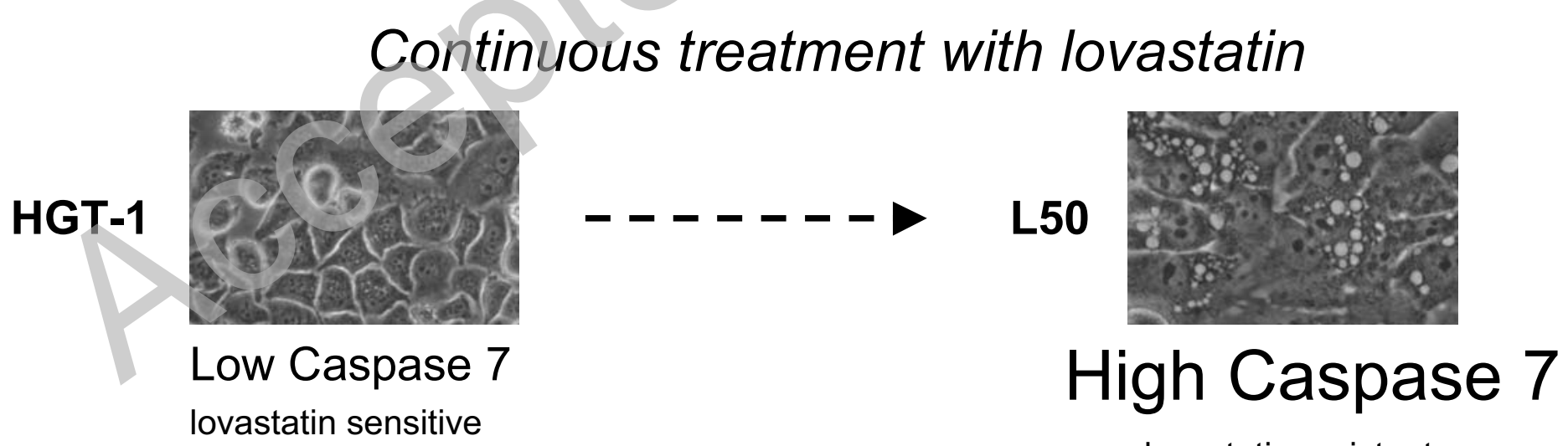

lovastatin resistant

\section{Figure 9}

Licenced copy. Copying is not permitted, except with prior permission and as allowed by law. (c) 2009 The Authors Journal compilation @ 2009 Portland Press Limited 